\title{
オオアジサシ東京都內にて獲らる
}

\section{Thalasseus bergii cristatus captured in Tokyo}

福 田信, 正

\section{Nobumasa Fukuda}

オオアジサシは熱帶性の鳥で我が国に於ては從来南鳥島、大東島（蕃殖） 琉球等より知られているのみであつた。然るに1947年8月31日東京都中野区 野方町の民家に本種の雄の幼鳥が 1 犲迷行し来つた。恐らく今回が本州に於 ける最初の記錄之思はれる。

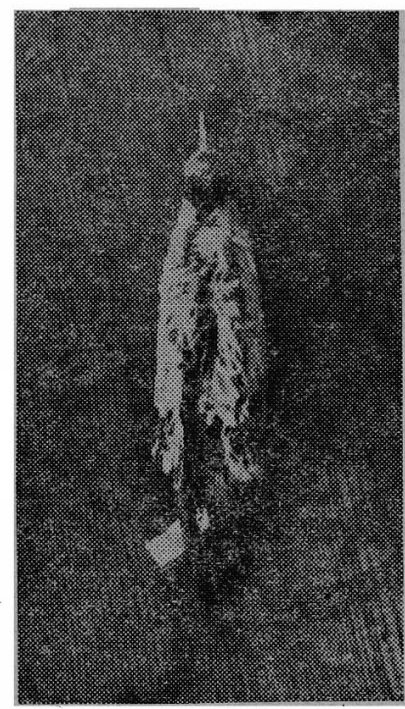

東京都內に於て獲られた オオアジサシ
体各部の測定は嘴 $43.5 \mathrm{~mm}$. 翼長 $290 \mathrm{~mm}$.

で成長よりか度り小さく又頭部は淡灰黑色で 成長よりうすく背部主色部が多く明らかに 幼鳥である事が制るのである。

該鳥经捕獲後飼育されたが同年10月 6 日に 消化器病の爲獘れた。な種の同定は餉育中 に粐山德太郎氏に敎示頂いた。

\section{Résumé}

A young Eastern Crested Tern captured in the city of Tokyo in August 31, 1947, forms the first record of this species from Honshu. 